\title{
Paclobutrazol Improves Sesame Yield by Increasing Dry Matter Accumulation and Reducing Seed Shattering Under Rainfed Conditions
}

\author{
Muhammad Zeeshan Mehmood ${ }^{1}$. Ghulam Qadir ${ }^{1}$. Obaid Afzal ${ }^{1}$ - Atta Mohi Ud Din ${ }^{2}$. Muhammad Ali Raza ${ }^{2}$. \\ Imran $\mathrm{Khan}^{3}$ - Muhammad Jawad Hassan ${ }^{3}$. Samrah Afzal Awan ${ }^{3}$. Shakeel Ahmad ${ }^{4}$ Muhammad Ansar ${ }^{1}$. \\ Muhammad Aqeel Aslam ${ }^{1} \cdot$ Mukhtar Ahmed $^{1,5}$ (i)
}

Received: 16 November 2020 / Accepted: 30 January 2021 / Published online: 12 February 2021

(c) The Author(s) 2021

\begin{abstract}
Several biotic and abiotic stresses significantly decrease the biomass accumulation and seed yield of sesame crops under rainfed areas. However, plant growth regulators (such as Paclobutrazol) can improve the total dry matter and seed production of the sesame crop. The effects of the paclobutrazol application on dry matter accumulation and seed yield had not been studied before in sesame under rainfed conditions. Therefore, a two-year field study during 2018 and 2019 was conducted with key objectives to assess the impacts of paclobutrazol on leaf greenness, leaf area, total dry matter production and partitioning, seed shattering, and seed yield of sesame. Two sesame cultivars (TS-5 and TS-3) were treated with four paclobutrazol concentrations $\left(\mathrm{P} 0=\right.$ Control, $\left.\mathrm{P} 1=100 \mathrm{mg} \mathrm{L}^{-1}, \mathrm{P} 2=200 \mathrm{mg} \mathrm{L}^{-1}, \mathrm{P} 3=300 \mathrm{mg} \mathrm{L}^{-1}\right)$. The experiment was executed in RCBDfactorial design with three replications. Compared with P0, treatment P3 improved the leaf greenness of sesame by $17 \%, 38 \%$, and $60 \%$ at 45,85 , and 125 days after sowing, respectively. However, P3 treatment decreased the leaf area of sesame by $14 \%$ and $20 \%$ at 45 and 85 days after sowing than P0, respectively. Compared with P0, treatment P3 increased the leaf area by $46 \%$ at 125 days after sowing. On average, treatment $\mathrm{P} 3$ also improved the total biomass production by $21 \%$ and partitioning in roots, stems, leaves, capsules, and seeds by $23 \%, 19 \%, 23 \%, 22 \%$, and $40 \%$, respectively, in the whole growing seasons as compared to P0. Moreover, under P3 treatment, sesame attained the highest seed yield and lowest seed shattering by $27 \%$ and 30\%, respectively, compared to P0. This study indicated that by applying the paclobutrazol concentration at the rate of $300 \mathrm{mg} \mathrm{L}^{-1}$ in sesame, the leaf greenness, leaf areas, biomass accumulation, partitioning, seed yield, and shatter resistance could be improved. Thus, the optimum paclobutrazol level could enhance the dry matter accumulation and seed production capacity of sesame by decreasing shattering losses under rainfed conditions.
\end{abstract}

Keywords Oilseed $\cdot$ Growth regulator $\cdot$ Leaf greenness $\cdot$ Leaf area $\cdot$ Seed number $\cdot$ Seed yield

Mukhtar Ahmed

mukhtar.ahmed@slu.se

1 Department of Agronomy, PMAS-Arid Agriculture University, Rawalpindi 46300, Pakistan

2 College of Agronomy, Sichuan Agricultural University, Chengdu 611130, China

3 Department of Grassland Science, Animal Science and Technology College, Sichuan Agricultural University, Chengdu 611130, China

4 Department of Agronomy, Bahauddin Zakariya University, Multan 60800, Pakistan

5 Department of Agricultural Research for Northern Sweden, Swedish University of Agricultural Sciences, 90183 Umeå, Sweden

\section{Introduction}

Sesame (Sesamum indicum L.) is the major conventional oilseed crop, specially grown in marginal lands and droughtprone areas under rainfed conditions (Pathak et al. 2014). It is one of the high oil containing oilseed crops ranging from 50 to $60 \%$, depending upon the variety (Raja et al. 2007; Wei et al. 2015). Sesame oil contains important antioxidants, i.e., sesamolin, and sesamol, which prevents its oil's rancidity (Rangkadilok et al. 2010), and its oil is a rich source of important unsaturated fatty acids, e.g., oleic acid (42\%) and linolenic acid (35\%) (Uzun et al. 2008). Additionally, the sesame meal contains ash $(5.27 \%)$, fiber $(6.22 \%)$, and 
carbohydrates $(28.14 \%)$ that are highly nutritious for livestock (Raza et al. 2018).

Several biotic and abiotic stresses adversely affect the yield components (i.e., capsule number per plant and seed number per capsule) of sesame, especially in rainfed regions (Jiang et al. 2009; Thornton et al. 2014). Among all these abiotic stresses, the high-temperature and drought are the most limiting factors, which negatively impact the growth and development of sesame in rainfed conditions (Ciaffi et al. 1996; Raza et al. 2018). However, selecting the suitable cultivars (e. g., drought-resistant varieties) and better agronomic management practices (e. g., appropriate sowing date) significantly increased the seed yield of crops (Raza et al. 2018). In addition to these constraints, seed shattering is another important factor that considerably decreases the sesame production.

Shattering is referred to the seed loss from ruptured capsules before or during the harvesting. Several factors are responsible for shattering losses, such as internal or external stresses, contact among the plant parts or harvest machinery, and fluctuations in temperature, humidity, and capsule moisture (Kadkol et al. 1984). However, these losses can be reduced to a certain extent by selecting shatter-resistant cultivar or through some innovative agronomic management options such as using plant growth regulators (Kuai et al. 2015). Several plant growth regulators like paclobutrazol, mepiquat chloride, and chlorocholine chloride were used effectively to regulate plant growth and development (Kumar et al. 2012). On top of that, Paclobutrazol application has been reported in earlier studies to minimize shattering losses in shatter-prone crops (Tripathi et al. 2003; Rajala et al. 2002). Moreover, paclobutrazol was effectively used to enhance the productivity and manage seed shattering in Birds-foot-trefoil (Lotus corniculatus L.) (Wiggans et al. 1956) and canola (Brassica napus L.) (Kuai et al. 2015).

Paclobutrazol is a triazole compound used to regulate the growth and physiological process in many plant species. Paclobutrazol regulates plants' growth and physiological functioning by interfering with sterol and gibberellic acid biosynthesis (Khalil and Rahman 1995; Khan 2009) that inhibits the oxidation of ent-kaurene to ent-kauronoic acid through inactivating cytochrome P-450 dependent oxygenase (Zhu et al. 2004; Rady and Gaballah 2012). Therefore, paclobutrazol could be used as stress protectants to regulate the plant water relations (such as capsule moisture) and shattering under stress conditions. Previous research findings have revealed that paclobutrazol application with appropriate concentration can significantly regulate the morphological and growth responses and improve the seed yield and shattering resistance of plants (Kuai et al. 2015; Zhou and Xi 1993; Armstrong and Nicol 1991; Baylis and Hutley-Bull 1991). Conversely, paclobutrazol application at high rates significantly reduced the crop yields (Guoping et al. 2001; Peng et al. 2014). Hence, the effects of paclobutrazol application on plant growth characteristics, seed yield, and shatter resistance could be erratic since they do not only depend on the plant potential but also interlinked with several other factors such as weather conditions, management practices, and plant responsiveness (Scarisbrick et al. 1985; Oswalt et al. 2014)

Thus, a comprehensive study was needed to determine paclobutrazol's optimum level for higher sesame production, especially under rainfed conditions. Therefore, a twoyear field study was initiated to understand the responses of sesame to paclobutrazol application. The key objectives of this study were to; (1) investigate the impacts of paclobutrazol application on biomass accumulation, seed yield, and yield components of sesame, and (2) determine the optimum paclobutrazol level to increase seed shatter resistance in sesame under rainfed conditions.

\section{Material and Methods}

\section{Research Site Description}

This field experiment was carried out at Koont-farm $\left(33^{\circ} 07^{\prime} 10.9^{\prime \prime} \mathrm{N}, 73^{\circ} 00^{\prime} 37.7^{\prime \prime} \mathrm{E}, 520 \mathrm{~m}\right.$ elevation), the research area of PMAS-Arid Agriculture University Rawalpindi, Province Punjab, Pakistan, during two growing seasons in 2018 and 2019, respectively. The climate of the research area falls under the dry sub-humid region with high rainfall. Weather data, including rainfall, maximum and minimum temperature of the experimental site for both growing seasons, are presented in Table 1. According to the world reference base for soil resources (2015) map,
Table 1 Monthly minimum temperature (Tmin), maximum temperature (Tmax), and rainfall during the growing seasons of 2018 and 2019

\begin{tabular}{|c|c|c|c|c|c|c|}
\hline \multirow[t]{2}{*}{ Month } & \multicolumn{3}{|l|}{2018} & \multicolumn{3}{|l|}{2019} \\
\hline & $\operatorname{Tmin}\left({ }^{\circ} \mathrm{C}\right)$ & $\operatorname{Tmax}\left({ }^{\circ} \mathrm{C}\right)$ & Rainfall (mm) & $\operatorname{Tmin}\left({ }^{\circ} \mathrm{C}\right)$ & $\operatorname{Tmax}\left({ }^{\circ} \mathrm{C}\right)$ & Rainfall (mm) \\
\hline July & 26.4 & 36.1 & 239.4 & 27.1 & 36.9 & 218.0 \\
\hline August & 25.6 & 34.1 & 211.0 & 24.9 & 34.2 & 122.4 \\
\hline September & 22.2 & 33.2 & 40.2 & 23.8 & 34.2 & 124.4 \\
\hline October & 16.6 & 30.1 & 28.4 & 17.3 & 28.9 & 24.3 \\
\hline November & 11.7 & 25.0 & 22.2 & 12.3 & 23.1 & 51.1 \\
\hline
\end{tabular}


the soil of the experimental site falls under the category of "durisols, calcisols, gypsisols, solonchaks, solonetz" with $\mathrm{pH} 7.2$, electrical conductivity $1.02 \mathrm{dSm}^{-1}$, available nitrogen $0.28 \mathrm{~g} \mathrm{~kg}^{-1}$, available phosphorus $2.5 \mathrm{~g} \mathrm{~kg}^{-1}$, available potassium $95 \mathrm{~g} \mathrm{~kg}^{-1}$, organic matter $0.55 \%$, saturation $34 \%$, and bulk density $1.23 \mathrm{~g} \mathrm{~cm}^{-3}$ in the topsoil layer of $20 \mathrm{~cm}$.

\section{Experimental Details}

This experiment was conducted in RCBD-factorial design with three replications. The field study consisted of two sesame cultivars (TS-5 and TS-3) and four paclobutrazol concentrations (P0-Control, P1-100, P2-200, and P3-300 mg $\left.\mathrm{L}^{-1}\right)$. Paclobutrazol treatments were applied twice with the same dose at the pre-reproductive (35 days after sowing) and late-bloom (80 days after sowing) stages following the previously published phenological scale (Langham 2007). Each plot's size was $30 \mathrm{~m}^{2}$ ( $6 \mathrm{~m}$ length $\times 5 \mathrm{~m}$ wide), and the total area of the experimental plots was $720 \mathrm{~m}^{2}\left(30 \mathrm{~m}^{2} \times 24\right.$ plots). We chose the pre-reproductive stage, to regulate the plant height and number of branches during early vegetative growth while the late bloom-stage to improve the seed yield and crop shatter resistance at the maturity. Paclobutrazol in liquid form was evenly mixed with distilled water, and each paclobutrazol treatment was foliar applied with a rechargeable electric knapsack sprayer.

Sesame was planted in the first week of July and harvested in the second week of November in both years. Sowing was performed with a single row hand-operated seed drill at the seeding depth of $2 \mathrm{~cm}$, and the seed rate was applied at $5 \mathrm{~kg} \mathrm{ha}^{-1}$. Row to row (R-R) and plant to plant (P-P) distance was maintained at $45 \mathrm{~cm}$ and $10 \mathrm{~cm}$, respectively, by over-seeding at sowing. Then thinning was done after fifteen days of germination, which resulted in the planting density of 200,000 plants ha ${ }^{-1}$. All the other recommended practices were performed uniformly in all experimental units.

\section{Measurements}

The crop phenological stages were determined by using a previously described phenological scale (Langham 2007). The leaf greenness of sesame plants was measured from each applied treatment at 45, 85, and 125 days after sowing (DAS). The chlorophyll meter SPAD-502 (Konica Minolta, Japan) was used for measuring the leaf greenness from different points of sesame plant, and then average values of SPAD were recorded at each interval. Similarly, the leaf area of sesame plants from all the applied treatments was determined at 45, 85, and 125 DAS. For this purpose, five sesame plants at each interval were destructively sampled from each experimental plot. The following formula was then used to determine the leaf area of sesame (Silva et al. 2002).
$\mathrm{AF}=(\mathrm{L} \times \mathrm{W}) \times \mathrm{f}$

where "AF" is the leaf area $\left(\mathrm{cm}^{2}\right)$ of sesame, "L" and "W" is the length and width of leaf, whereas " $\mathrm{f}$ " is the correction factor, which is 0.70 for sesame.

The biomass accumulation and partitioning in sesame plants were measured at 45,85 , and 125 DAS by destructive sampling. Fifteen sesame plants from each treatment were harvested manually, including the roots by carefully digging the soil, and roots were rinsed with water to remove adhering soil. Then all the plants were separated into roots, leaves, stems, capsules, and seeds. All the plant organs were ovendried first at $105{ }^{\circ} \mathrm{C}$ for one hour to kill the fresh tissues, then at $70{ }^{\circ} \mathrm{C}$ to obtain the constant weight for total biomass accumulation and partitioning analysis (Raza et al. 2019).

When more than $90 \%$ of capsules attained the mature capsule color, twenty representative plants from the two central rows of each sub-plot were harvested manually using a sickle; bundles were made and sundried for one week by keeping the plants in a vertical direction. After drying, plants were threshed manually to determine the seed yield and yield components (number of capsules plant ${ }^{-1}$, number of seeds capsule $^{-1}$, and thousand seed weight) of sesame under the applied treatments. Twenty representative plants from each plot were selected, and the number of capsules plant ${ }^{-1}$ was counted, and then the average number of capsules plant ${ }^{-1}$ was calculated. For the number of seeds capsule ${ }^{-1}$, hundred capsules were randomly taken from each plot at harvesting, then capsules were threshed to count the number of seeds capsule $^{-1}$, and the average was calculated. Similarly, for a thousand seed weight, three lots of thousand sources from bulk seed lot of each plot were oven-dried at $65{ }^{\circ} \mathrm{C}$ to attain the constant weight. Thousand seed weight was measured using electrical balance, and the average was calculated. Seed yield was determined by manually threshing the sundried bundles from each plot and then converted to $\mathrm{kg} \mathrm{ha}^{-1}$.

The sesame seed shatter resistance under the studied treatments was measured by comparing the seed losses among shattered and non-shattered capsules. Hundred nonshattered and hundred shattered capsules were clipped from the plants of each treatment. Capsules were threshed manually to obtain seed weight and compared to calculate the shattering losses and shattering percentage for sesame under different paclobutrazol treatments (Gan et al. 2008).

\section{Statistics Analysis}

Statistical analysis was performed with Statistix 8.1 (V.8.1, Statistix, USA). Significant differences among cultivars and paclobutrazol treatments were computed using a two-way Analysis of Variance (ANOVA) technique combined with the least significant difference (LSD) Test. The significance of the difference between 
means was evaluated at a 5\% probability level $(p<0.05)$. The Shapiro-Wilk and Kolmogorov-Smirnov normality tests were conducted to confirm that the data can be subjected to analysis of regression (Montgomery 2017). Afterwards linear regression analysis was conducted between paclobutrazol doses and grain yield to see impacts of treatments.

\section{Results}

\section{Leaf Greenness}

The paclobutrazol application significantly enhanced the leaf greenness of the sesame plant at 45,85 , and 125 DAS. Treatment P3 had the greatest influence on the leaf greenness of sesame plants compared to control (Fig. 1). For instance, the average across the years, treatment P3 $\left(300 \mathrm{mg} \mathrm{L}^{-1}\right)$
2018

a TS-5

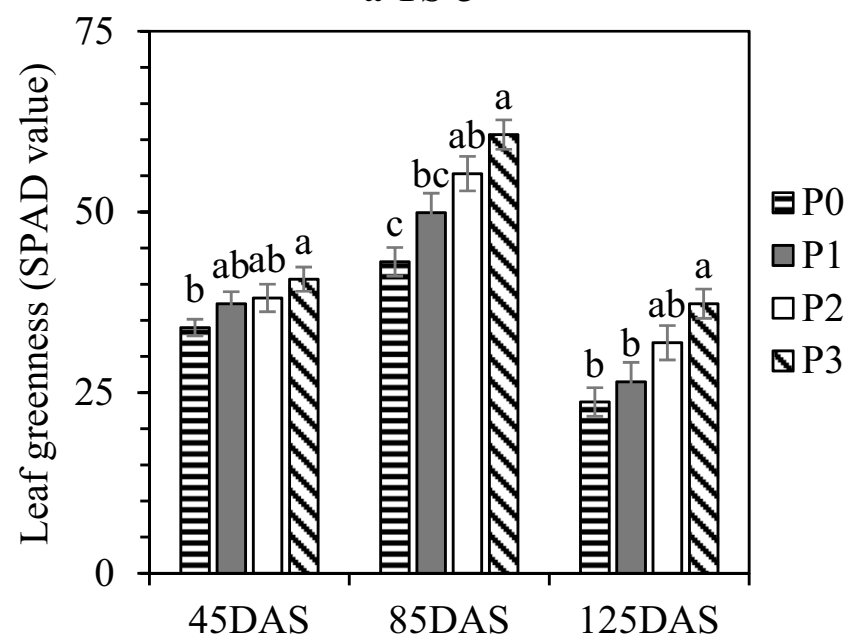

b TS-3

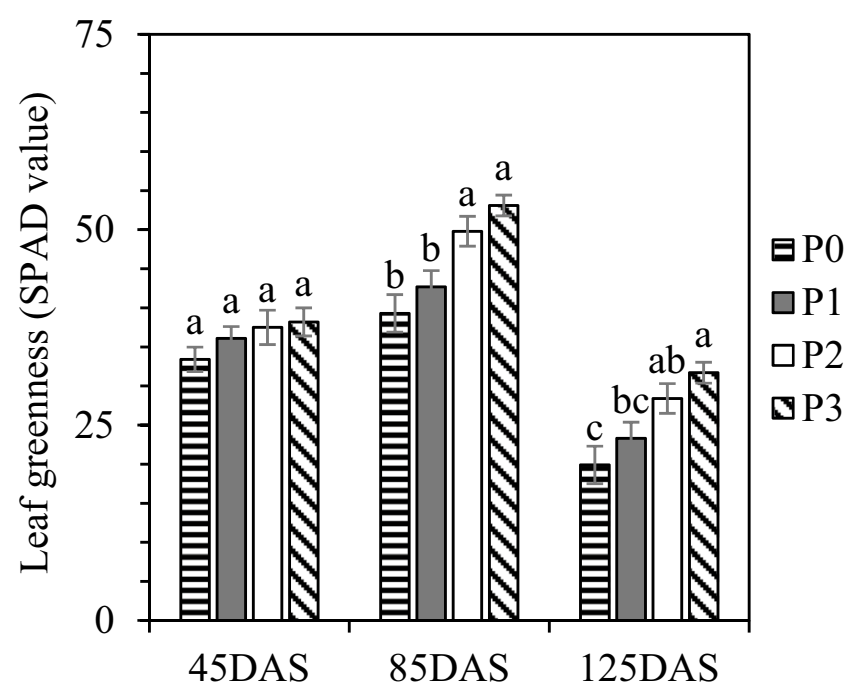

2019

c TS-5

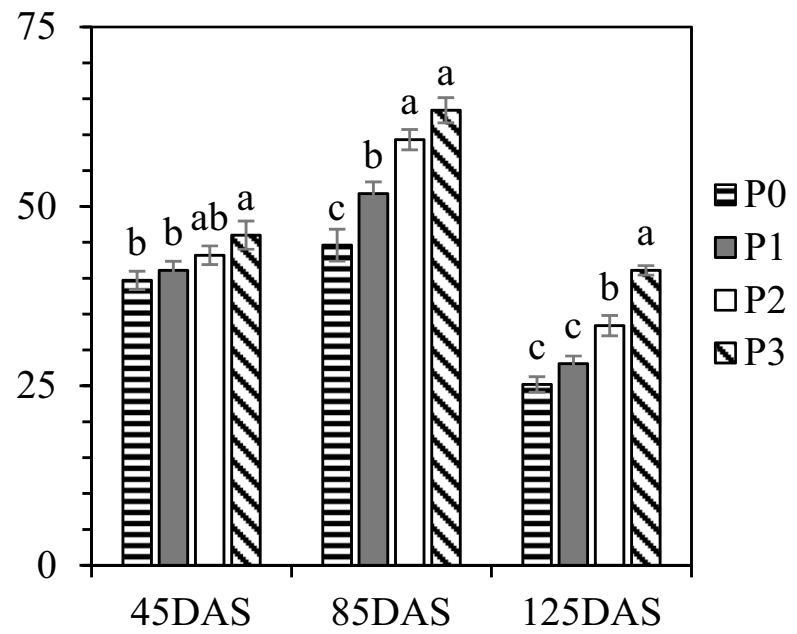

d TS-3

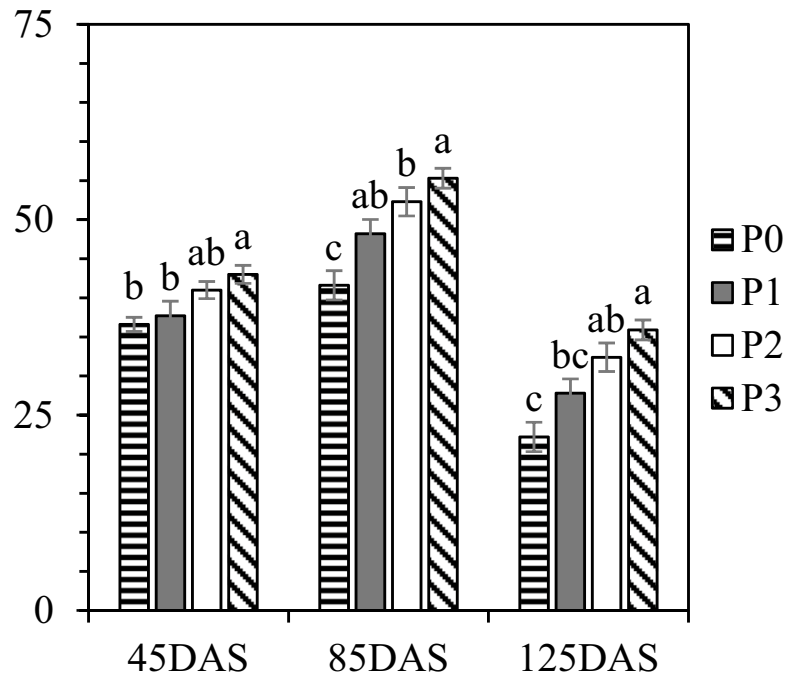

Fig. 1 Leaf greenness of sesame at 45, 85, and 125 days after sowing (DAS) in 2018 and 2019. The P0, P1, P2, and P3 represent the paclobutrazol treatments, Control, $100 \mathrm{mg} \mathrm{L}^{-1}, 200 \mathrm{mg} \mathrm{L}^{-1}$, and $300 \mathrm{mg} \mathrm{L}^{-1}$, respectively. Means are averaged over three replicates 
increased the leaf greenness of sesame plants by $17 \%, 38 \%$, and $60 \%$ at 45,85 , and 125 DAS, respectively, than the control treatment, indicating that the paclobutrazol application can significantly improve the leaf greenness of the sesame plant.

\section{Leaf Area}

The paclobutrazol application significantly $(p<0.05)$ influenced the leaf area of the sesame plant at 45,85 , and 125
DAS in both cultivars, except the non-significant difference, was observed between cultivars at 45 DAS in 2018 and 2019, respectively. Overall, compared to control, paclobutrazol concentration P3 $\left(300 \mathrm{mg} \mathrm{L}^{-1}\right)$ had the greatest impact on the leaf area of sesame at all intervals. On average, over the years, in comparison to control, paclobutrazol application P3 (300 $\mathrm{mg} \mathrm{L}^{-1}$ ) decreased the leaf area of sesame by $14 \%$ and $25 \%$ at 45 and 85 DAS, respectively. However, P3 (300 $\mathrm{mg} \mathrm{L}^{-1}$ ) treatment showed a higher leaf area by $46 \%$ compared to control at 125 DAS (Fig. 2). In this two-year
2018

a TS-5

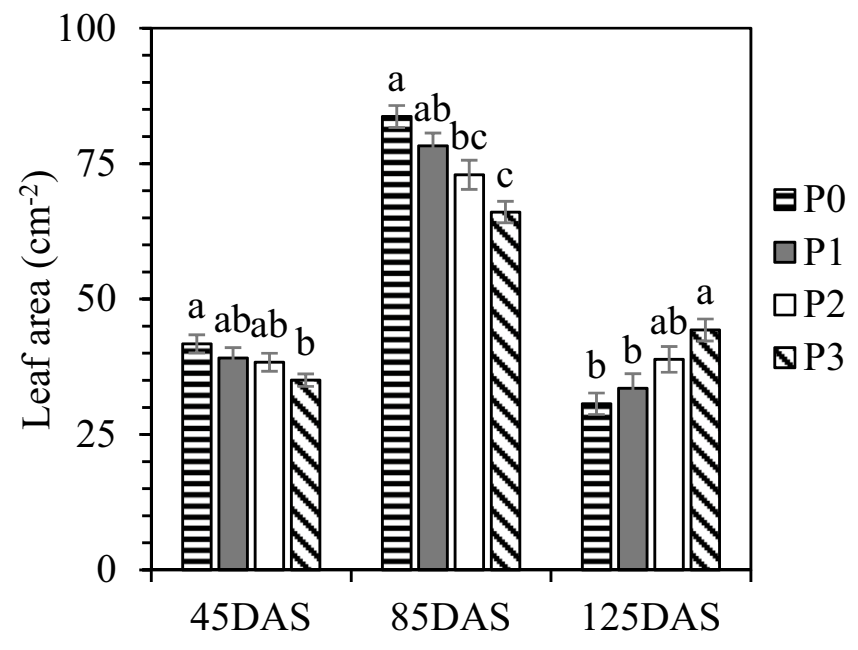

b TS-3

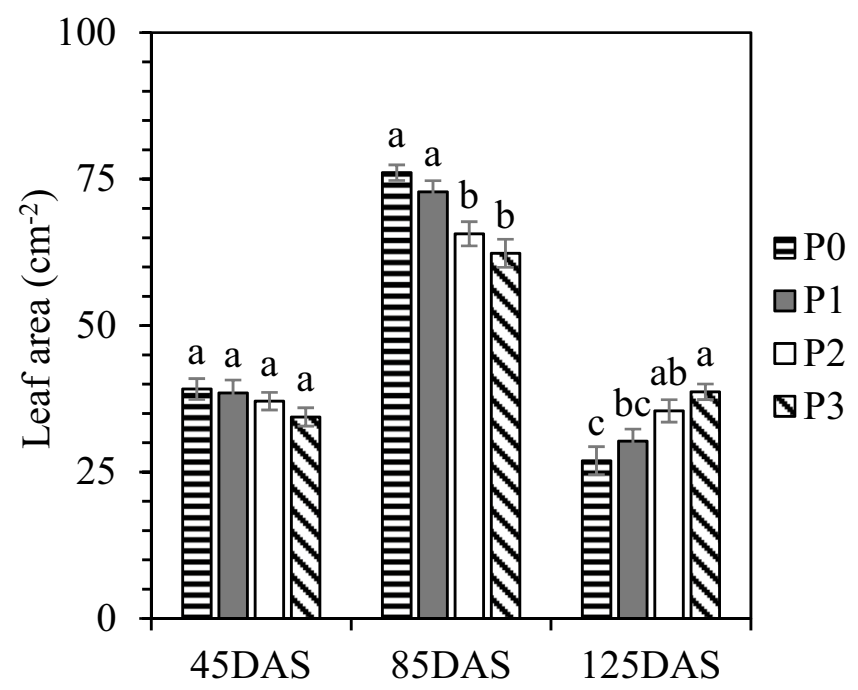

2019

c TS-5

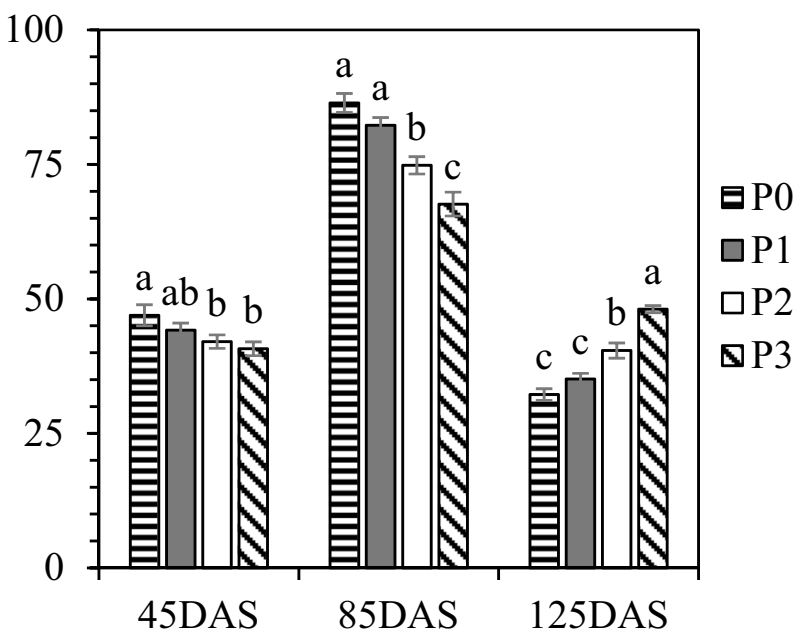

d TS-3

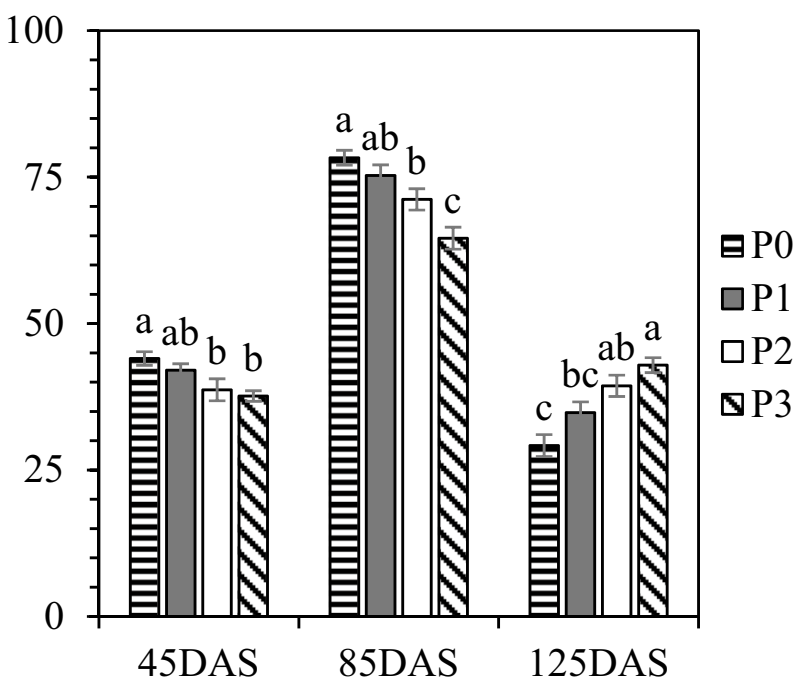

Fig. 2 Leaf area of sesame plants at 45, 85, and 125 days after sowing (DAS) in 2018 and 2019. The P0, P1, P2, and P3 represent the paclobutrazol treatments, Control, $100 \mathrm{mg} \mathrm{L}^{-1}, 200 \mathrm{mg} \mathrm{L}^{-1}$, and $300 \mathrm{mg} \mathrm{L}^{-1}$, respectively. Means are averaged over three replicates 
experiment, results suggested that leaf area development in sesame was directly associated with paclobutrazol concentrations.

\section{Biomass Accumulation}

Different paclobutrazol concentrations had a significant $(p<0.05)$ impact on total biomass accumulation (TBA) of sesame (Table 2). Overall, across the years, P3 (300 mg L $\left.{ }^{-1}\right)$ produced the highest biomass of sesame $(388.2,1029.8$ and $898.2 \mathrm{~g} \mathrm{~m}^{-2}$ in 2018 and $401.9,1076.5$ and $972.4 \mathrm{~g} \mathrm{~m}^{-2}$ in 2019) than the control $\left(323.9,845.5\right.$ and $715.9 \mathrm{~g} \mathrm{~m}^{-2}$ in 2018 and $346.5,907.5$ and $783.1 \mathrm{~g} \mathrm{~m}^{-2}$ in 2019) at 45,85 , and 125 DAS, respectively. Paclobutrazol concentration P3 ( $300 \mathrm{mg} \mathrm{L}^{-1}$ ) increased the total biomass accumulation of sesame plant by $20 \%, 16 \%$, and $22 \%$ in 2018 , and $19 \%, 25 \%$, and $24 \%$ in 2019 , at 45,85 , and 125 DAS, respectively.

\section{Biomass Partitioning}

Paclobutrazol application with various concentrations significantly altered the biomass partitioning patterns in various plant organs of the sesame. Overall, in all the treatments, P0 depicted the lowest biomass gains in the different plant parts at 45, 85, and 125 DAS (Fig. 3). Seed biomass of sesame at maturity was highest (137.0 and $145.9 \mathrm{~g} \mathrm{~m}^{-2}$ ) in P3

Table 2 Effects of paclobutrazol application on total biomass accumulation of sesame in 2018 and 2019

\begin{tabular}{llllll}
\hline Year & Treatment & & 45 DAS & 85 DAS & 125 DAS \\
\hline 2018 & Cultivar & TS-5 & $362.4 \mathrm{a}$ & $976.6 \mathrm{a}$ & $849.9 \mathrm{a}$ \\
& & TS-3 & $357.0 \mathrm{a}$ & $904.7 \mathrm{~b}$ & $777.9 \mathrm{~b}$ \\
& LSD & & 19.3 & 19.4 & 27.7 \\
& Paclobutrazol & P0 & $323.9 \mathrm{c}$ & $845.5 \mathrm{~d}$ & $715.9 \mathrm{~d}$ \\
& & P1 & $354.9 \mathrm{~b}$ & $910.6 \mathrm{c}$ & $790.4 \mathrm{c}$ \\
& & P2 & $371.7 \mathrm{ab}$ & $976.8 \mathrm{~b}$ & $851.2 \mathrm{~b}$ \\
& & P3 & $388.2 \mathrm{a}$ & $1029.8 \mathrm{a}$ & $898.2 \mathrm{a}$ \\
& LSD & & 27.3 & 27.5 & 39.1 \\
& Cultivar & TS-5 & $377.5 \mathrm{a}$ & $1033.5 \mathrm{a}$ & $920.4 \mathrm{a}$ \\
& & TS-3 & $367.8 \mathrm{a}$ & $949.3 \mathrm{~b}$ & $835.2 \mathrm{~b}$ \\
& LSD & & 14.0 & 30.2 & 32.7 \\
& Paclobutrazol & P0 & $346.5 \mathrm{c}$ & $907.5 \mathrm{~d}$ & $783.1 \mathrm{~d}$ \\
& & P1 & $360.0 \mathrm{c}$ & $952.0 \mathrm{c}$ & $836.9 \mathrm{c}$ \\
& & P2 & $382.0 \mathrm{~b}$ & $1029.7 \mathrm{~b}$ & $918.7 \mathrm{~b}$ \\
& & P3 & $401.9 \mathrm{a}$ & $1076.5 \mathrm{a}$ & $972.4 \mathrm{a}$ \\
& & 19.8 & 42.6 & 46.2 \\
\hline
\end{tabular}

The 45 DAS, 85DAS, and 125 DAS represent the sampling intervals at 45 days after sowing, 85 days after sowing, and 125 days after sowing, respectively. The $\mathrm{P} 0, \mathrm{P} 1, \mathrm{P} 2$, and $\mathrm{P} 3$ represent the paclobutrazol treatments, Control, $100 \mathrm{mg} \mathrm{L}^{-1}, 200 \mathrm{mg} \mathrm{L}^{-1}$, and $300 \mathrm{mg} \mathrm{L}^{-1}$, respectively. Means are averaged over three replicates and the means with a different letter in the column varied significantly at $p<0.05$
(300 $\mathrm{mg} \mathrm{L}^{-1}$ ) treatment and lowest (109.3 and $117.3 \mathrm{~g} \mathrm{~m}^{-2}$ ) in P0 treatment in both years, respectively. On average, across both years, P3 $\left(300 \mathrm{mg} \mathrm{L}^{-1}\right)$ was the only treatment that increased the root (by 26\%, 19\%, and 23\%), stem (by $16 \%, 17 \%$, and $23 \%$ ), and leaves (by $17 \%, 16 \%$, and $34 \%$ ) biomass at 45, 85 and 125 DAS while capsule hull (by 23\% and 22\%) and seed (by 55\% and 25\%) biomass at 85 and 125 DAS respectively as compared to control.

\section{Yield Components}

Yield components of sesame were significantly affected by various application concentrations of paclobutrazol (Table 3). The number of capsules plant ${ }^{-1}$, number of seeds capsule $^{-1}$, and thousand seed weight were altered considerably in P3 treatment relative to other application concentrations. Specifically, the mean maximum values of the number of capsules plant ${ }^{-1}$ (33.0 and 33.7) and thousand seed weight (3.67 and $3.74 \mathrm{~g}$ ) were observed in P3 $\left(300 \mathrm{mg} \mathrm{L}^{-1}\right)$. In contrast, the maximum average seeds capsule ${ }^{-1}$ (63.8 and 64.3) was observed in control during 2018 and 2019, respectively. Furthermore, P3 (300 $\mathrm{m} \mathrm{L}^{-1}$ ) treatment increased the number of capsules plant ${ }^{-1}$ by $26 \%$ and $25 \%$ and thousand seed weight by $10 \%$ and $11 \%$ compared to control in both years, respectively.

\section{Seed Yield}

Sesame seed yield was significantly $(p<0.05)$ higher in P3 (300 mg L $\mathrm{m}^{-1}$ ) treatment (1379.1 and $1435.5 \mathrm{~kg} \mathrm{ha}^{-1}$ ) compared with P2 (1303.4 and $\left.1384.3 \mathrm{~kg} \mathrm{ha}^{-1}\right)$, P1 (1208.8 and $1263.1 \mathrm{~kg} \mathrm{ha}^{-1}$ ), and P0 (1083.2 and $1141.8 \mathrm{~kg} \mathrm{ha}^{-1}$ ) in 2018 and 2019 respectively (Table 3). Importantly in paclobutrazol treatments, across the years, P3 $\left(300 \mathrm{mg} \mathrm{L}^{-1}\right)$ was the only treatment that enhanced the seed yield of sesame by $27 \%$ and $26 \%$ in comparison with control. The seed yield of sesame increased linearly in response to paclobutrazol application (Fig. 4). Furthermore, TS-5 had a higher seed yield (1302.7 and $1368.7 \mathrm{~kg} \mathrm{ha}^{-1}$ ) than the TS-3 (1184.5 and $1243.6 \mathrm{~kg} \mathrm{ha}^{-1}$ ) in both years. Overall, TS-5 showed the average greater seed yield by $10 \%$ than the TS-3 in both growing seasons (Table 3 ).

\section{Seed Shattering Losses and Percentage}

Sesame seed shattering losses were significantly reduced with the paclobutrazol application (Fig. 5). Among the paclobutrazol concentrations, sesame plants in P3 (300 mg L $\left.{ }^{-1}\right)$ treatment had the lowest (20.50 and $19.57 \mathrm{~g} \mathrm{~m}^{-2}$ ) shattering losses than the control (24.65 and $24.02 \mathrm{~g} \mathrm{~m}^{-2}$ ). Paclobutrazol treatment P3 (300 mg L ${ }^{-1}$ ), decreased the shattering losses in sesame by $17 \%$ and $19 \%$ in 2018 and 2019, respectively. Similarly, the lowest shattering 

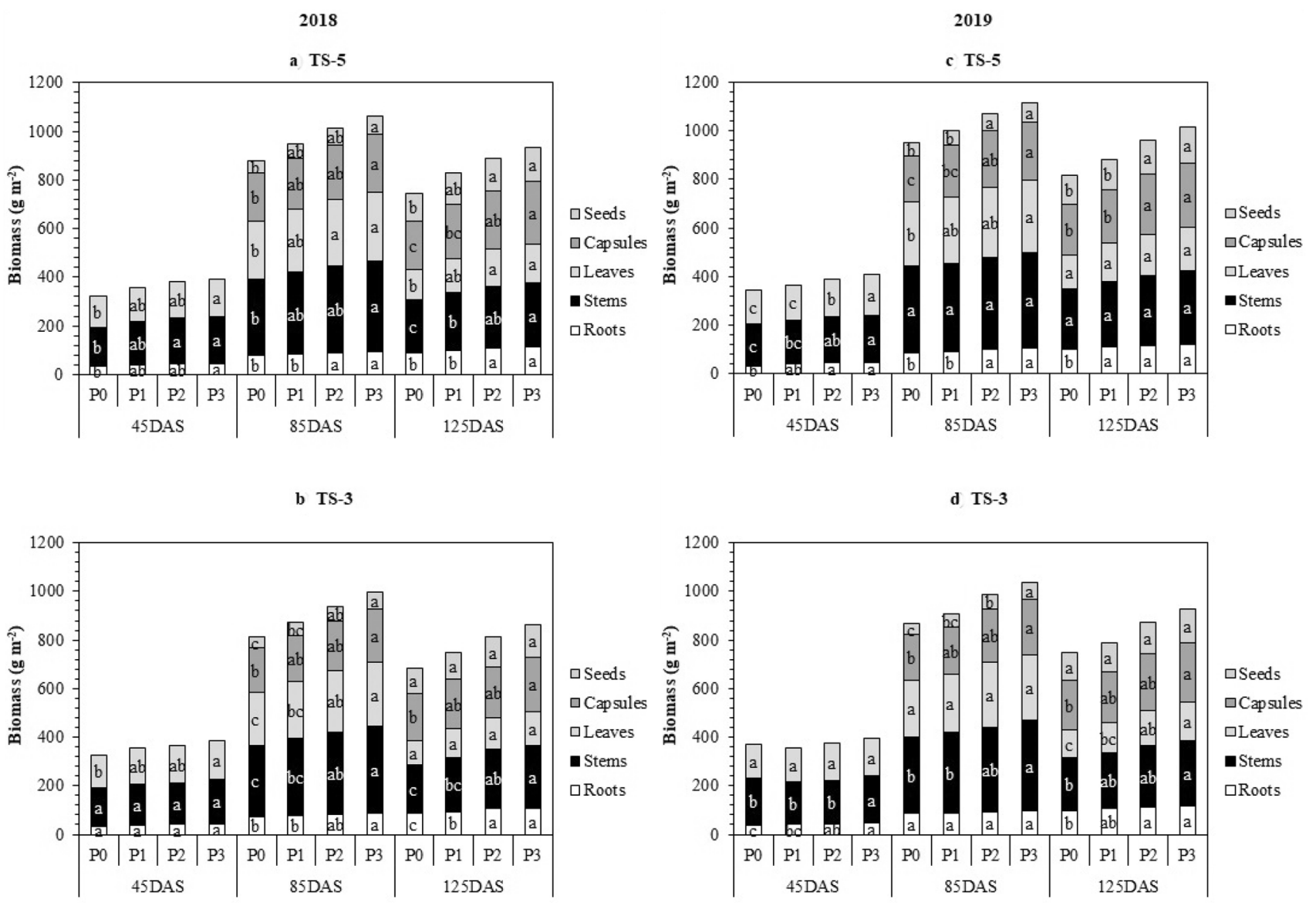

Fig. 3 Biomass partitioning of sesame plants at 45, 85, and 125 days after sowing (DAS) in 2018 and 2019. The P0, P1, P2, and P3 represent the paclobutrazol treatments, Control, $100 \mathrm{mg} \mathrm{L}^{-1}, 200 \mathrm{mg} \mathrm{L}^{-1}$, and $300 \mathrm{mg} \mathrm{L}^{-1}$, respectively. Means are averaged over three replicates

percentage was recorded in $\mathrm{P} 3\left(300 \mathrm{mg} \mathrm{L}^{-1}\right)$ treatment $(13.1$ and 12.2) as compared with control (18.6 and 17.5) (Fig. 6). However, between the cultivars, TS-5 had the lower seed yield losses and percentage compared to TS-3. On average, across the years, TS- 5 had the lower seed yield losses by $2 \%$ and shattering percentage by $9 \%$ compared to TS-3.

\section{Linear Regression Analysis and Normality Test}

The results of linear regression analysis showed significant relationship between paclobutrazol application and seed yield of sesame (Fig. 4). The equation obtained using Shapiro-Wilk and Kolmogorov-Smirnov normality test was:

Grainyield $=1026.815+99.231 \times$ paclobutrazolconcentrations

The coefficient of determination $\left(\mathrm{R}^{2}\right)$ of linear model was 0.453 while obtained adjusted $R^{2}$ was 0.441 . The validation of model can be confirmed by the $\mathrm{F}$ test as presented in Table 4.

\section{Discussion}

Our findings demonstrated significant improvements in the leaf greenness of sesame plants under increasing paclobutrazol concentrations. A previous study reported that the application of triazoles significantly increased the chlorophyll contents of soybean leaves by regulating the expression of key enzymes involved in the biosynthesis of chlorophyll (Liu et al. 2015). Moreover, evidence suggested that application of triazoles increase the chlorophyll contents, photosynthetic rate of leaves, and delay leaf senescence in plants (Yan et al. 2015). Results of this study were in line with earlier studies where plant growth regulators especially triazoles enhanced the chlorophyll synthesis and delayed leaf senescence in different crops (Liu et al. 2015; Wang et al. 2009; Ahmad et al. 2019).

Leaf area of sesame was significantly reduced at higher concentrations that indicate the growth retarding effects of paclobutrazol on plants (Soumya et al. 2017; Pal et al. 2016). Specifically, paclobutrazol interferes with gibberellic acid synthesis by impairing the 
Table 3 Effects of paclobutrazol application on yield components and seed yield of sesame in 2018 and 2019

\begin{tabular}{|c|c|c|c|c|c|c|}
\hline Year & Treatment & & $\begin{array}{l}\text { Number of } \\
\text { capsules } \\
\left(\text { plant }^{-1}\right)\end{array}$ & $\begin{array}{l}\text { Number of seeds } \\
\left(\text { capsule }^{-1}\right)\end{array}$ & $\begin{array}{l}\text { Thousand seed } \\
\text { weight } \\
\text { (g) }\end{array}$ & $\begin{array}{l}\text { Seed yield } \\
\left(\mathrm{kg} \mathrm{ha}^{-1}\right)\end{array}$ \\
\hline \multirow[t]{8}{*}{2018} & \multirow[t]{2}{*}{ Cultivar } & TS-5 & $30.8 \mathrm{a}$ & $61.5 \mathrm{a}$ & $3.56 \mathrm{a}$ & $1302.7 \mathrm{a}$ \\
\hline & & TS-3 & $29.7 \mathrm{a}$ & $58.0 \mathrm{~b}$ & $3.47 \mathrm{a}$ & $1184.5 b$ \\
\hline & LSD & & 2.0 & 3.1 & 0.12 & 93.5 \\
\hline & \multirow[t]{4}{*}{ Paclobutrazol } & P0 & $26.2 \mathrm{c}$ & $63.8 \mathrm{a}$ & $3.33 b$ & $1083.2 \mathrm{c}$ \\
\hline & & P1 & $29.8 \mathrm{~b}$ & $60.5 \mathrm{ab}$ & $3.43 b$ & $1208.8 \mathrm{bc}$ \\
\hline & & $\mathrm{P} 2$ & $31.8 \mathrm{ab}$ & $57.7 \mathrm{~b}$ & $3.62 \mathrm{a}$ & $1303.4 \mathrm{ab}$ \\
\hline & & $\mathrm{P} 3$ & $33.0 \mathrm{a}$ & $56.8 \mathrm{~b}$ & $3.67 \mathrm{a}$ & $1379.1 \mathrm{a}$ \\
\hline & LSD & & 2.9 & 4.3 & 0.17 & 132.2 \\
\hline \multirow[t]{8}{*}{2019} & \multirow[t]{2}{*}{ Cultivar } & TS-5 & $31.7 \mathrm{a}$ & $61.9 \mathrm{a}$ & $3.62 \mathrm{a}$ & $1368.7 \mathrm{a}$ \\
\hline & & TS-3 & $30.3 \mathrm{a}$ & $58.7 \mathrm{~b}$ & $3.52 \mathrm{a}$ & $1243.6 b$ \\
\hline & LSD & & 2.7 & 3.0 & 0.11 & 122.8 \\
\hline & \multirow[t]{4}{*}{ Paclobutrazol } & P0 & $27.0 \mathrm{~b}$ & $64.3 \mathrm{a}$ & $3.38 \mathrm{~b}$ & $1141.8 b$ \\
\hline & & P1 & $30.5 \mathrm{ab}$ & $61.0 \mathrm{ab}$ & $3.49 \mathrm{~b}$ & $1263.1 \mathrm{ab}$ \\
\hline & & P2 & $32.8 \mathrm{a}$ & $58.7 \mathrm{~b}$ & $3.69 \mathrm{a}$ & $1384.3 \mathrm{a}$ \\
\hline & & P3 & $33.7 \mathrm{a}$ & $57.3 b$ & $3.74 a$ & $1435.5 \mathrm{a}$ \\
\hline & LSD & & 3.9 & 4.2 & 0.15 & 173.7 \\
\hline
\end{tabular}

The P0, P1, P2, and P3 represent the paclobutrazol treatments, Control, $100 \mathrm{mg} \mathrm{L}^{-1}, 200 \mathrm{mg} \mathrm{L}^{-1}$, and $300 \mathrm{mg} \mathrm{L}^{-1}$, respectively. Means are averaged over three replicates and the means with a different letter in the column varied significantly at $p<0.05$

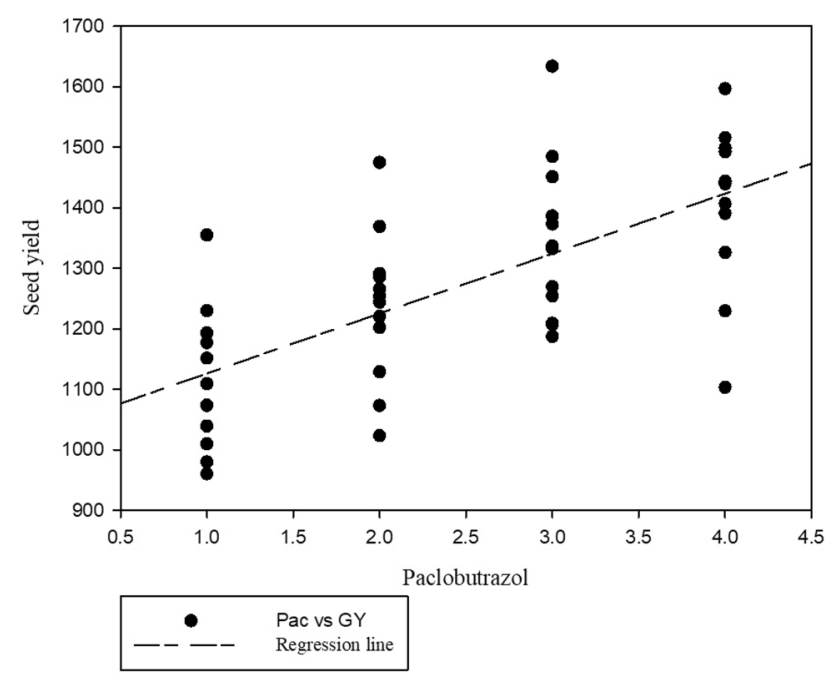

Fig. 4 Linear regression analysis for paclobutrazol vs seed yield of sesame. The 1.0, 2.0, 3.0, and 4.0 represent the paclobutrazol treatments, Control, $100 \mathrm{mg} \mathrm{L}^{-1}, 200 \mathrm{mg} \mathrm{L}^{-1}$, and $300 \mathrm{mg} \mathrm{L}^{-1}$, respectively

oxidation of ent-kaurene to ent-kauronoic acid by inactivating cytochrome P450-dependent oxygenase (Zhu et al. 2004; Rady and Gaballah 2012). However, at maturity, the leaf area was significantly higher in P3 $\left(300 \mathrm{mg} \mathrm{L}^{-1}\right)$ treatment linked with delayed leaf senescence and stayed green leaf characteristics, as paclobutrazol treated plants have darker green foliage and more chlorophyll content (Jiang et al.
2019; Tesfahun 2018). It is well established that delayed leaf senescence could enhance the photosynthates formation and mobilization from leaves towards the reproductive tissues of the plant, which could potentially improve the seed yield (Feng et al. 2019; Gregersen 2011). Additionally, it could promote the nutrients remobilization from senescing leaves to developing organs (Joshi et al. 2019). Thus, optimization of paclobutrazol concentration can provide an opportunity for yield improvements due to the better source-sink relationship and delayed leaf senescence (Ahmad et al. 2019; Wang et al. 2009; Upadhyaya et al. 1985).

The current experiment demonstrates that the exogenous application of paclobutrazol significantly altered the total biomass accumulation and partitioning patterns in sesame. Moreover, our results revealed that total biomass accumulation was highest in P3 $\left(300 \mathrm{mg} \mathrm{L}^{-1}\right)$ treatment than nontreated plants. Enhanced nutrient and water translocation within the plants under paclobutrazol application increase the biomass production of plants (Kamran et al. 2018; Kuai et al. 2015). Furthermore, P3 (300 mg L $\left.{ }^{-1}\right)$ treatment changed the biomass partitioning in plant organs and the root and seed biomass of sesame. On average, during both years, it increased the root and seed biomass (by 23\% and $25 \%$, respectively) compared to control at maturity. Changes in biomass partitioning (especially in seeds) might be associated with better root architecture, which enhanced that nutrient and water translocation in the plant (Kamran et al. 2018). However, an increase in root biomass was interlinked with enhanced row formation in cortical cells due to 
a TS-5

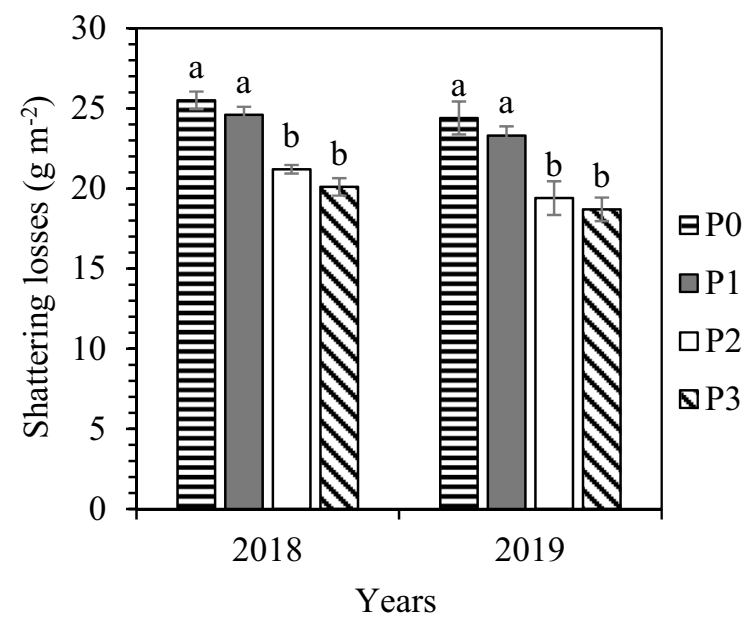

b TS-3

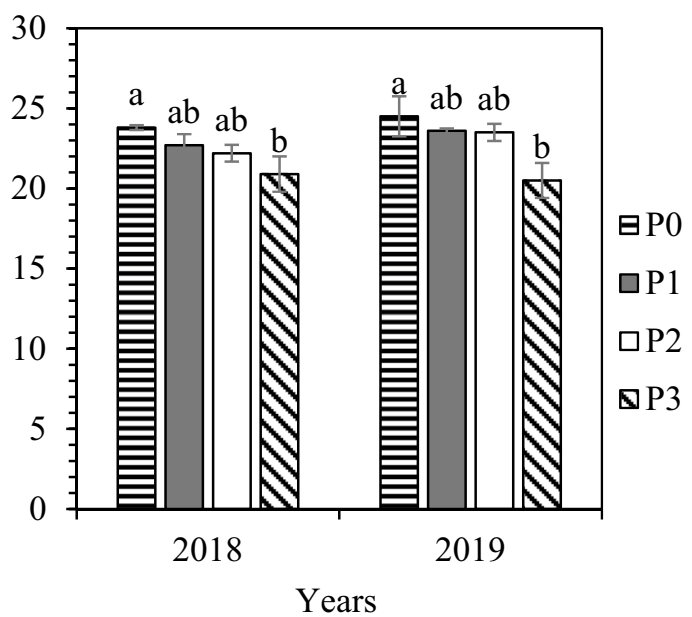

Fig. 5 Shattering losses in 2018 and 2019. The P0, P1, P2, and P3 represent the paclobutrazol treatments, Control, $100 \mathrm{mg} \mathrm{L}^{-1}, 200 \mathrm{mg} \mathrm{L}^{-1}$, and $300 \mathrm{mg} \mathrm{L}^{-1}$, respectively. Means are averaged over three replicates

a TS-5

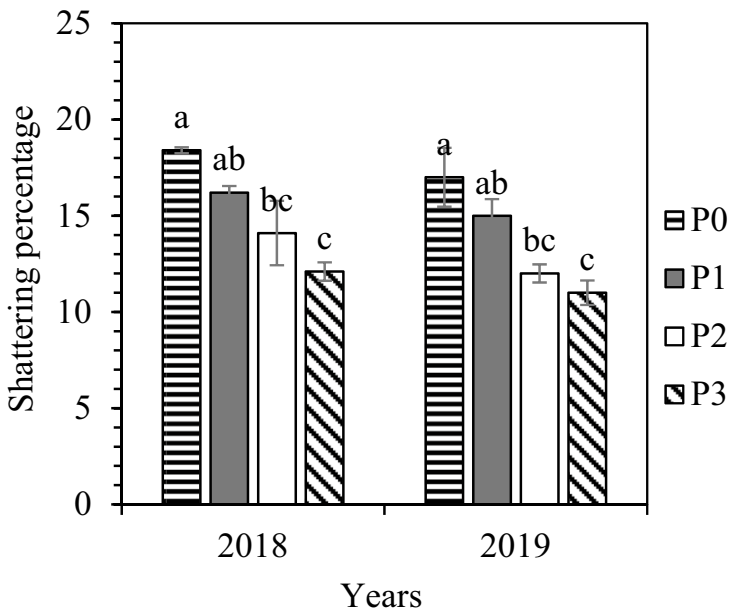

b TS-3

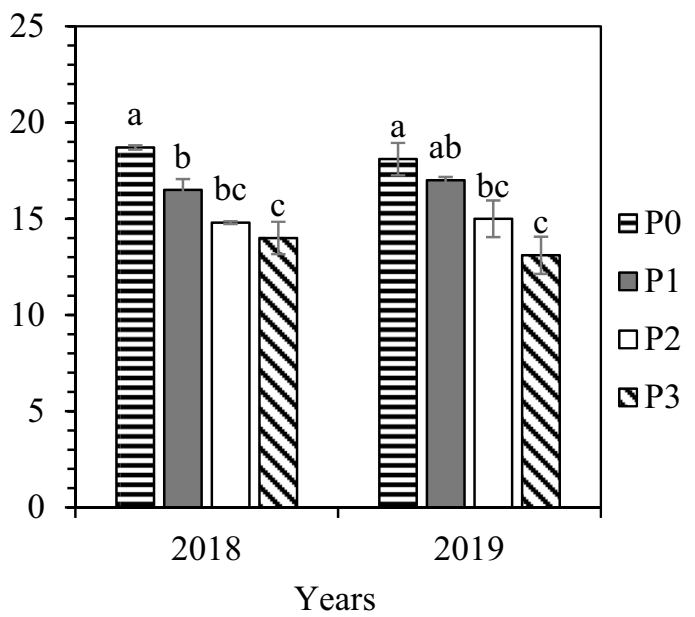

Fig. 6 Shattering percentage in 2018 and 2019. The P0, P1, P2, and P3 represent the paclobutrazol treatments, Control, $100 \mathrm{mg} \mathrm{L}^{-1}, 200 \mathrm{mg}$ $\mathrm{L}^{-1}$, and $300 \mathrm{mg} \mathrm{L}^{-1}$, respectively. Means are averaged over three replicates

plant growth regulators (Fletcher et al. 2000; Barnes et al. 1989; Burrows et al. 1992). Plant treatment with triazoles increases the root extension, radical cell expansion (Wang and Li 1992), and association with larger parenchyma cells (Fletcher et al. 2000), which results in increased root biomass in comparison with non-treated plants (Qi et al. 2012; Kamran et al. 2018). In past reports, a similar trend was reported for root biomass in maize (Wan-rong et al. 2014), wheat (Hajihashemi et al. 2007), and soybean (Yan et al. 2010) under the paclobutrazol application.

Seed yield differences under different levels of the paclobutrazol application were also evaluated in this study. Sesame yield increased linearly in response to the doses of paclobutrazol application. Seed yield of oilseed crops is determined by different yield contributing traits, such as the number of capsules, number of seeds per capsule, and seed weight (Wang et al. 2011). In the current study, different paclobutrazol levels caused significant variations in these yield components of sesame. It is well understood and reported that paclobutrazol at specific concentrations promotes flower initiation (Wilkinson and Richards 1987), flower bud formation (Blanco 1988; Kaska et al. 1991), and economic yield (Kuai et al. 2015; Kamran et al. 2018) in several plant species. Consistently, an increase in the number of capsules under different paclobutrazol treatments in sesame may be due to the stimulation of flower 
Table 4 Linear regression analysis between paclobutrazol application and seed yield of sesame using Normality Test (Shapiro-Wilk)

\begin{tabular}{|c|c|c|c|c|c|}
\hline & & Coefficient & Std. error & $\mathrm{t}$ & $\mathrm{P}$ \\
\hline Constant & & 1026.815 & 44.049 & 23.311 & $<0.001$ \\
\hline Paclobutrazol & & 99.231 & 16.084 & 6.169 & $<0.001$ \\
\hline \multicolumn{6}{|c|}{ Analysis of Variance } \\
\hline & DF & SS & MS & $\mathrm{F}$ & $\mathrm{P}$ \\
\hline Regression & 1 & $590,807.4$ & $590,807.4$ & 38.062 & $<0.001$ \\
\hline Residual & 46 & $714,031.1$ & $15,522.42$ & & \\
\hline Total & 47 & $1,304,839$ & $27,762.52$ & & \\
\hline
\end{tabular}

where $\mathrm{DF}=$ degree of freedom, $\mathrm{SS}=$ sum of squares, $\mathrm{MS}=$ Mean squares, Normality Test (Shapiro-Wilk): Passed $(\mathrm{P}=0.936)$, Constant Variance Test: Passed $(\mathrm{P}=0.991)$ and Power of performed test with alpha $=0.050: 1.000$, Normality Test (Kolmogorov-Smirnov) $\mathrm{Passed}(\mathrm{P}=0.467)$, Constant Variance Test: Passed $(\mathrm{P}=0.991)$ and Power of performed test with alpha $=0.050: 1.000$

bud formation and flower initiation. Similarly, paclobutrazol increases the average fruit size in Crimson Gold (Blanco 1988) and seed weight in canola and maize, while it has the tendency to reduce the seeds number per capsule at higher application concentrations (Kamran et al. 2018; Kuai et al. 2015). Reduced seeds per capsule were observed under studied paclobutrazol treatments, while greatest reduction was recorded in P3 (300 $\mathrm{mg} \mathrm{L}^{-1}$ ) treatment. However, decreased seeds number per capsule helped to relieve the competition for nutrient allocation in seeds (Nahar and Ikeda 2002), which consequently increased the thousand seed weight and seed yield in sesame. Moreover, seed yield and crop growth are closely linked with root architecture, because it determines the acquisition, uptake, and utilization of mineral nutrients and water (Qi et al. 2012). Hence, in rainfed farming conditions, where ample supply of water and nutrient is not possible, improved root architecture under paclobutrazol application will enhance plant access to non-uniformly distributed nutrients and water, that could increase the crops yield (Zhang et al. 2009; Kamran et al. 2018).

The impact of different paclobutrazol levels on shattering losses was investigated, and the findings of this experiment demonstrated that seed shattering was significantly reduced under P3 (300 $\left.\mathrm{mg} \mathrm{L}^{-1}\right)$ treatment in both years. The possible increase in shattering resistance may be attributed to paclobutrazol effects on capsule maturity (Gan et al. 2008), capsule wall thickness (Child et al. 2003), capsule dry weight, and water content (Kuai et al. 2015). In past investigations, plant growth regulators and different kinds of desiccants were successfully used to control the vegetative growth and shattering losses in various crops (Wiggans et al. 1956; Kuai et al. 2015). Metcalfe et al. (1957) reported that the water content of the capsule is a critical determining factor for shattering losses and could facilitate in improving the shattering resistance of the crops. However, mechanisms involved in changing the structure, biochemistry, and shatter resistance under paclobutrazol application, still lack a comprehensive understanding and need further investigation (Kuai et al. 2015).

\section{Limitations and Implications}

During this study, we noted the following limitations during sampling and measurements. The method used to determine leaf area is not comprehensive and accurate because sesame has large leaf shape variations. Still, the equation only considers a single correction factor for all of them. Therefore, results may not reflect the considerable variation in sesame leaves. Moreover, the method used for seed shattering measurement was reported earlier to assess the seed shattering in sesame, but it also had some limitations. For instance, this method does not assume the variations in seed weight of different capsules, which can greatly vary. Additionally, the paclobutrazol can significantly influence the size and weight of capsules in the top, middle, and bottom of the plant. Thus, these limitations can affect the results obtained using these methods.

This study highlights the paclobutrazol's effects on leaf greenness, leaf area, biomass accumulation and distribution, seed yield, and seed shattering. Thus, we present the following implications for improvement in sesame production. Our results suggested that paclobutrazol application can enhance the seed yield and reduce the seed shattering in sesame. Additionally, these findings could also be used for developing the shattering resistance in sesame, which will favor the mechanical harvesting of sesame that will improve the farming system efficiency and net returns. Furthermore, to the best of our knowledge, this research is the first to report the effects of paclobutrazol application on dry matter accumulation, seed yield, and shatter resistance in sesame under rainfed conditions. 


\section{Conclusion}

Our study revealed that different paclobutrazol concentrations significantly impacted the leaf greenness, leaf area, and leaf senescence of sesame. Similarly, the total biomass accumulation and partitioning of sesame significantly improved under the application of paclobutrazol, which ultimately increased the total seed biomass. Hence, improved leaf greenness and leaf area may have delayed the leaf senescence and improved dry matter accumulation, which finally enhanced the sesame's final seed yield. Moreover, paclobutrazol application significantly reduced the shattering losses. Overall, the paclobutrazol concentration of $300 \mathrm{mg} \mathrm{L}^{-1}$ produced the highest seed yield and lowest seed shattering. Thus, our two-year field study results suggest that sesame yield and shatter resistance in sesame could be enhanced by applying optimum paclobutrazol level.

Funding Open access funding provided by Swedish University of Agricultural Sciences. This research was supported by the Pakistan Agricultural Research Council (PARC) under the Agricultural Linkages Program (ALP) on "Research for Productivity Enhancement of Drought Tolerant and Shattering Resistant Cultivars of Sesame in Rainfed Areas of Punjab Pakistan".

\section{Compliance with Ethical Standards}

Conflicts of interest Authors did not have any conflict of interest.

Open Access This article is licensed under a Creative Commons Attribution 4.0 International License, which permits use, sharing, adaptation, distribution and reproduction in any medium or format, as long as you give appropriate credit to the original author(s) and the source, provide a link to the Creative Commons licence, and indicate if changes were made. The images or other third party material in this article are included in the article's Creative Commons licence, unless indicated otherwise in a credit line to the material. If material is not included in the article's Creative Commons licence and your intended use is not permitted by statutory regulation or exceeds the permitted use, you will need to obtain permission directly from the copyright holder. To view a copy of this licence, visit http://creativecommons.org/licenses/by/4.0/.

\section{References}

Ahmad, I., Kamran, M., Su, W., Haiqi, W., Ali, S., Bilegjargal, B., et al. (2019). Application of uniconazole improves photosynthetic efficiency of maize by enhancing the antioxidant defense mechanism and delaying leaf senescence in semiarid regions. Journal of Plant Growth Regulation, 38(3), 855-869. https://doi.org/10.1007/ s00344-018-9897-5.

Armstrong, E., \& Nicol, H. (1991). Reducing height and lodging in rapeseed with growth regulators. Australian Journal of Experimental Agriculture, 31(2), 245-250. https://doi.org/10.1071/ EA9910245.

Barnes, A., Walser, R., \& Davis, T. (1989). Anatomy of Zea mays and Glycine max seedlings treated with triazole plant growth regulators. Biologia Plantarum, 31(5), 370-375. https://doi. org/10.1007/BF02876355.

Baylis, A., \& Hutley-Bull, P. (1991). The effects of a paclobutrazolbased growth regulator on the yield, quality and ease of management of oilseed rape. Annals of Applied Biology, 118(2), 445-452. https://doi.org/10.1111/j.1744-7348.1991.tb05645.x.

Blanco, A. (1988). Control of shoot growth of peach and nectarine trees with paclobutrazol. Journal of Horticultural Science, 63(2), 201-207. https://doi.org/10.1080/14620316.1988.11515848.

Burrows, G., Boag, T., \& Stewart, W. (1992). Changes in leaf, stem, and root anatomy of Chrysanthemum cv. Lillian Hoek following paclobutrazol application. Journal of Plant Growth Regulation, 11(4), 189. https://doi.org/10.1007/BF02115476.

Child, R., Summers, J., Babij, J., Farrent, J., \& Bruce, D. (2003). Increased resistance to pod shatter is associated with changes in the vascular structure in pods of a resynthesized Brassica napus line. Journal of Experimental Botany, 54(389), 1919-1930. https ://doi.org/10.1093/jxb/erg209.

Ciaffi, M., Tozzi, L., Borghi, B., Corbellini, M., \& Lafiandra, D. (1996). Effect of heat shock during grain filling on the gluten protein composition of bread wheat. Journal of Cereal Science, 24(2), 91-100. https://doi.org/10.1006/jcrs.1996.0042.

Feng, L., Raza, M. A., Li, Z., Chen, Y., Khalid, M. H. B., Du, J., et al. (2019). The influence of light intensity and leaf movement on photosynthesis characteristics and carbon balance of soybean. Frontiers in Plant Science, 9, 1952. https://doi.org/10.3389/ fpls.2018.01952.

Fletcher, R. A., Gilley, A., Sankhla, N., \& Davis, T. D. (2000). Triazoles as plant growth regulators and stress protectants. Horticultural Reviews, 24, 55-138. https://doi.org/10.1002/9780470650 776.ch3.

Gan, Y., Malhi, S., Brandt, S., \& McDonald, C. (2008). Assessment of seed shattering resistance and yield loss in five oilseed crops. Canadian Journal of Plant Science, 88(1), 267-270. https://doi. org/10.4141/CJPS07028.

Gregersen, P. L. (2011). Senescence and nutrient remobilization in crop plants. The Molecular and Physiological Basis of Nutrient Use Efficiency in Crops. https://doi.org/10.1002/9780470960707.

Guoping, Z., Jianxing, C., \& Bull, D. A. (2001). The effects of timing of $\mathrm{N}$ application and plant growth regulators on morphogenesis and yield formation in wheat. Plant Growth Regulation, 35(3), 239-245. https://doi.org/10.1023/A:1014411316780.

Hajihashemi, S., Kiarostami, K., Saboora, A., \& Enteshari, S. (2007). Exogenously applied paclobutrazol modulates growth in saltstressed wheat plants. Plant Growth Regulation, 53(2), 117-128. https://doi.org/10.1007/s10725-007-9209-8.

Jiang, D., Yue, H., Wollenweber, B., Tan, W., Mu, H., Bo, Y., et al. (2009). Effects of post-anthesis drought and waterlogging on accumulation of high-molecular-weight glutenin subunits and glutenin macropolymers content in wheat grain. Journal of Agronomy and Crop Science, 195(2), 89-97. https://doi.org/10.1111/j.1439037X.2008.00353.x.

Jiang, X., Wang, Y., Xie, H., Li, R., Wei, J., \& Liu, Y. (2019). Environmental behavior of paclobutrazol in soil and its toxicity on potato and taro plants. Environmental Science and Pollution Research, 26(26), 27385-27395. https://doi.org/10.1007/s11356-019-05947 $-9$

Joshi, S., Choukimath, A., Isenegger, D., Panozzo, J., Spangenberg, G., \& Kant, S. (2019). Improved wheat growth and yield by delayed leaf senescence using developmentally regulated expression of a cytokinin biosynthesis gene. Frontiers in Plant Science, 10, 1285. https://doi.org/10.3389/fpls.2019.01285.

Kadkol, G., Macmillan, R., Burrow, R., \& Halloran, G. (1984). Evaluation of Brassica genotypes for resistance to shatter. I. Development of a laboratory test. Euphytica, 33(1), 63-73. https://doi. org/10.1007/BF00022751. 
Kamran, M., Wennan, S., Ahmad, I., Xiangping, M., Wenwen, C., et al. (2018). Application of paclobutrazol affect maize grain yield by regulating root morphological and physiological characteristics under a semi-arid region. Scientific Reports, 8(1), 1-15. https:// doi.org/10.1038/s41598-018-23166-z.

Kaska, N., Kuden, A., \& Kuden, A. (1991). Physiological effects of PP333 (paclobutrazol) on golden delicious apple cultivars. Journal of Cairo University Agricultural Faculty, 5(4), 87-94. https:// doi.org/10.1007/s00344-013-9353-5.

Khalil, I. A., \& Rahman, H.-U. (1995). Effect of paclobutrazol on growth, chloroplast pigments and sterol biosynthesis of maize (Zea mays L.). Plant Science, 105(1), 15-21. https://doi. org/10.1016/0168-9452(94)04028-F.

Khan, M. (2009). Sterol biosynthesis inhibition by paclobutrazol induces greater aluminum (Al) sensitivity in AI-tolerant rice. American Journal of Plant Physiology, 4(3), 89-99. https://doi. org/10.3923/ajpp.2009.89.99.

Kuai, J., Yang, Y., Sun, Y., Zhou, G., Zuo, Q., Wu, J., et al. (2015). Paclobutrazol increases canola seed yield by enhancing lodging and pod shatter resistance in Brassica napus L. Field Crops Research, 180, 10-20. https://doi.org/10.1016/j.fcr.2015.05.004.

Kumar-Ghatty, S., Satyanarayana, J., Guha, A., Chaitanya, B., \& Reddy, A. R. (2012). Paclobutrazol treatment as a potential strategy for higher seed and oil yield in field-grown Camelina sativa L. Crantz. BMC Research Notes, 5(1), 137. https://doi. org/10.1186/1756-0500-5-137.

Langham, D. R. (2007). Phenology of sesame. In A. S. H. S. Press (Ed.), Issues in New Crops and New Uses, Janick \& Whipkey (pp. 144-182). Alexandria: ASHS Press.

Liu, Y., Fang, Y., Huang, M., Jin, Y., Sun, J., Tao, X., et al. (2015). Uniconazole-induced starch accumulation in the bioenergy crop duckweed (Landoltia punctata) II: Transcriptome alterations of pathways involved in carbohydrate metabolism and endogenous hormone crosstalk. Biotechnology for Biofuels, 8(1), 1-12. https ://doi.org/10.1186/s13068-015-0245-8.

Metcalfe, D., Johnson, I., \& Shaw, R. (1957). The relation between pod dehiscence, relative humidity and moisture equilibrium in birdsfoot trefoil, lotus corniculatus 1. Agronomy Journal, 49(3), 130-134. https://doi.org/10.2134/agronj1957.000219620049000 30006x.

Montgomery, D. C. (2017). Design and Analysis of Experiments. Hoboken: Wiley.

Nahar, B. S., \& Ikeda, T. (2002). Effect of different concentrations of Figaron on production and abscission of reproductive organs, growth, and yield in soybean (Glycine max L.). Field Crops Research, 78(1), 41-50. https://doi.org/10.1016/S0378 -4290(02)00086-2.

Oswalt, J., Rieff, J. M., Severino, L. S., Auld, D. L., Bednarz, C. W., \& Ritchie, G. L. (2014). Plant height and seed yield of castor (Ricinus communis L.) sprayed with growth retardants and harvest aid chemicals. Industrial Crops and Products, 61, 272-277. https:// doi.org/10.1016/j.indcrop.2014.07.006.

Pal, S., Zhao, J., Khan, A., Yadav, N. S., Batushansky, A., Barak, S., et al. (2016). Paclobutrazol induces tolerance in tomato to deficit irrigation through diversified effects on plant morphology, physiology and metabolism. Scientific Reports, 6, 39321. https://doi. org/10.1038/srep39321.

Pathak, N., Rai, A. K., Kumari, R., Thapa, A., \& Bhat, K. V. (2014). Sesame crop: An underexploited oilseed holds tremendous potential for enhanced food value. Agricultural Sciences, 2014(5), 519529. https://doi.org/10.4236/as.2014.56054.

Peng, D., Chen, X., Yin, Y., Lu, K., Yang, W., Tang, Y., et al. (2014). Lodging resistance of winter wheat (Triticum aestivum L.): Lignin accumulation and its related enzymes activities due to the application of paclobutrazol or gibberellin acid. Field Crops Research, 157, 1-7. https://doi.org/10.1016/j.fcr.2013.11.015.
Qi, W.-Z., Liu, H.-H., Liu, P., Dong, S.-T., Zhao, B.-Q., So, H. B., et al. (2012). Morphological and physiological characteristics of corn (Zea mays L.) roots from cultivars with different yield potentials. European Journal of agronomy, 38, 54-63. https://doi. org/10.1016/j.eja.2011.12.003.

Rady, M. M., \& Gaballah, M. S. (2012). Improving barley yield grown under water stress conditions. Research Journal of Recent Sciences, 1(6), 1-6.

Raja, A., Hattab, K. O., Gurusamy, L., \& Suganya, S. (2007). Sulphur levels on nutrient uptake and yield of sesame varieties and nutrient availability. International Journal of Soil Science, 2(4), 278-285. https://doi.org/10.3923/ijss.2007.278.285.

Rajala, A., Peltonen-Sainio, P., Onnela, M., \& Jackson, M. (2002). Effects of applying stem-shortening plant growth regulators to leaves on root elongation by seedlings of wheat, oat and barley: Mediation by ethylene. Plant Growth Regulation, 38(1), 51-59. https://doi.org/10.1023/A:1020924307455.

Rangkadilok, N., Pholphana, N., Mahidol, C., Wongyai, W., Saengsooksree, K., Nookabkaew, S., et al. (2010). Variation of sesamin, sesamolin and tocopherols in sesame (Sesamum indicum L.) seeds and oil products in Thailand. Food Chemistry, 122(3), 724-730. https://doi.org/10.1016/j.foodchem.2010.03.044.

Raza, M. A., Feng, L. Y., Manaf, A., Wasaya, A., Ansar, M., Hussain, A., et al. (2018). Sulphur application increases seed yield and oil content in sesame seeds under rainfed conditions. Field Crops Research, 218, 51-58. https://doi.org/10.1016/j.fcr.2017.12.024.

Raza, M. A., Feng, L. Y., van der Werf, W., Iqbal, N., Khan, I., Hassan, M. J., et al. (2019). Optimum leaf defoliation: A new agronomic approach for increasing nutrient uptake and land equivalent ratio of maize soybean relay intercropping system. Field Crops Research, 244, 107647. https://doi.org/10.1016/j.fcr.2019.107647.

Global Soil Map. (2015). https://www.isric.org/sites/default/files/ WRBSoilMap.pdf. Accessed 1 Jul 2021.

Scarisbrick, D., Addo-Quaye, A., Daniels, R., \& Mahamud, S. (1985). The effect of paclobutrazol on plant height and seed yield of oil-seed rape (Brassica napus L.). The Journal of Agricultural Science, 105(3), 605-612. https://doi.org/10.1017/S002185960 0059517.

Silva, L., Santos, J., Vieira, D., Beltrão, N., Alves, I., \& Jerônimo, J. (2002). Simple method to estimate leaf area of sesame plants (Sesamum indicum L.). Brazilian Journal of Oilseeds and Fibrous, 6, 491-495.

Soumya, P., Kumar, P., \& Pal, M. (2017). Paclobutrazol: a novel plant growth regulator and multi-stress ameliorant. Indian Journal of Plant Physiology, 22(3), 267-278. https://doi.org/10.1007/s4050 2-017-0316-x.

Tesfahun, W. (2018). A review on: Response of crops to paclobutrazol application. Cogent Food \& Agriculture, 4(1), 1525169. https:// doi.org/10.1080/23311932.2018.1525169.

Thornton, P. K., Ericksen, P. J., Herrero, M., \& Challinor, A. J. (2014). Climate variability and vulnerability to climate change: A review. Global Change Biology, 20(11), 3313-3328. https://doi. org/10.1111/gcb.12581.

Tripathi-Sayre, K., Kaul, J., \& Narang, R. (2003). Growth and morphology of spring wheat (Triticum aestivum L.) culms and their association with lodging: Effects of genotypes, $\mathrm{N}$ levels and ethephon. Field Crops Research, 84(3), 271-290. https://doi. org/10.1016/S0378-4290(03)00095-9.

Upadhyaya, A., Sankhla, D., Davis, T. D., Sankhla, N., \& Smith, B. (1985). Effect of paclobutrazol on the activities of some enzymes of activated oxygen metabolism and lipid peroxidation in senescing soybean leaves. Journal of Plant Physiology, 121(5), 453-461. https://doi.org/10.1016/S0176-1617(85)80081-X.

Uzun, B., Arslan, Ç., \& Furat, Ş. (2008). Variation in fatty acid compositions, oil content and oil yield in a germplasm collection of sesame (Sesamum indicum L.). Journal of the American Oil 
Chemists' Society, 85(12), 1135-1142. https://doi.org/10.1007/ s11746-008-1304-0.

Wan-rong, G., Yao, M., Jun-bao, Z., Biao, J., Yong-chao, W., Jing, L., et al. (2014). Regulation of foliar application DCPTA on growth and development of maize seedling leaves in Heilongjiang Province. Journal of Northeast Agricultural University (English Edition), 21(2), 1-11. https://doi.org/10.1016/S1006-8104(14)60028 -3 .

Wang, L.-H., \& Li, C.-H. (1992). The effect of paclobutrazol on physiological and biochemical changes in the primary roots of pea. Journal of Experimental Botany, 43(10), 1367-1372. https://doi. org/10.1093/jxb/43.10.1367.

Wang, X., Mathieu, A., Cournède, P.-H., Allirand, J.-M., Jullien, A., de Reffye, P., et al. (2011). Variability and regulation of the number of ovules, seeds and pods according to assimilate availability in winter oilseed rape (Brassica napus L.). Field Crops Research, 122(1), 60-69. https://doi.org/10.1016/j.fcr.2011.02.008.

Wang, X., Yang, W., Chen, G., Li, Q., \& Wang, X. (2009). Effects of spraying uniconazole on leaf senescence and yield of maize at late growth stage. Journal of Maize Sciences, 17(1), 86-88.

Wei, X., Liu, K., Zhang, Y., Feng, Q., Wang, L., Zhao, Y., et al. (2015). Genetic discovery for oil production and quality in sesame. Nature Communications, 6, 8609. https://doi.org/10.1038/ncomms9609.

Wiggans, S., Metcalfe, D., \& Thompson, H. (1956). The use of desiccant sprays in harvesting birdsfoot trefoil for seed. Agronomy Journal, 48(7), 281-284. https://doi.org/10.2134/agronj1956 $.00021962004800070001 x$.
Wilkinson, R., \& Richards, D. (1987). Effects of paclobutrazol on growth and flowering of Bouvardia humboldtii. HortScience, 22(3), 444-445.

Yan, Y., Gong, W., Yang, W., Wan, Y., Chen, X., Chen, Z., et al. (2010). Seed treatment with uniconazole powder improves soybean seedling growth under shading by corn in relay strip intercropping system. Plant Production Science, 13(4), 367-374. https://doi. org/10.1626/pps.13.367.

Yan, Y., Wan, Y., Liu, W., Wang, X., Yong, T., Yang, W., et al. (2015). Influence of seed treatment with uniconazole powder on soybean growth, photosynthesis, dry matter accumulation after flowering and yield in relay strip intercropping system. Plant Production Science, 18(3), 295-301. https://doi.org/10.1626/pps.18.295.

Zhang, X., Chen, S., Sun, H., Wang, Y., \& Shao, L. (2009). Root size, distribution and soil water depletion as affected by cultivars and environmental factors. Field Crops Research, 114(1), 75-83. https ://doi.org/10.1016/j.fcr.2009.07.006.

Zhou, W., \& Xi, H. (1993). Effects of mixtalol and paclobutrazol on photosynthesis and yield of rape (Brassica napus). Journal of Plant Growth Regulation, 12(3), 157-161. https://doi. org/10.1007/BF00189647.

Zhu, L.-H., van de Peppel, A., Li, X.-Y., \& Welander, M. (2004). Changes of leaf water potential and endogenous cytokinins in young apple trees treated with or without paclobutrazol under drought conditions. Scientia Horticulturae, 99(2), 133-141. https ://doi.org/10.1016/S0304-4238(03)00089-X. 